\title{
Screening and Mechanism of Antagonist Peptide for CC Chemokine Receptor 1 (CCR1) Derived from Viral Macrophage Inflammatory Protein II
}

\author{
Sha Liu, Qing Ding, Pijin Wei, Hanxiao Sun*, Xiuying Li, Guijie An, Yan Yang \\ and Jingguang Zhou \\ Institute of Genomic Medicine, College of Pharmacy, Jinan University, Guangzhou 510632, China
}

*For correspondence: Email: sunhx718@163.com; Tel: +86-020-38375022

Received: 11 February 2014

Revised accepted: 20 April 2014

\begin{abstract}
Purpose: To search for effective antagonist peptide of CC chemokine receptor 1 (CCR1), and evaluate the potential role and mechanism of peptide C18P derived from viral macrophage inflammatory protein II (vMIP-II).

Methods: Alignment, simulated peptide-cut, bioinformatics and protease digestion were used to screen and prepare antagonist peptide. Interactions between C18P and CCR1 were determined by radioligand binding assays and ${ }^{35}$ SJGTPYS binding experiment. Chemotaxis assay was utilized to assess the potency for inducing or inhibiting peripheral blood mononuclear cells (PBMCs) migration. Ligandinduced intracellular calcium mobilization was tested by flow cytometry.

Results: A peptide containing 18 amino acids (C18P) was screened. C18P bound to CCR1 with a Kd of $5.7 \mathrm{ng} / \mathrm{ml}$ and displaced ${ }^{125}$ I-labeled MIP-1a and ${ }^{125}$ I-labeled RANTES on human CCR1-transfected HEK293 cells (IC $50=11.2$ and $9.6 \mathrm{ng} / \mathrm{ml}$, respectively) in radioligand binding studies. C18P lacked intrinsic agonist activity but strongly inhibited HCC-1 (100 nM) induced ${ }^{35}$ SJGTPYS binding $\left(I C_{50}=3.7\right.$ $\mathrm{ug} / \mathrm{ml})$, chemotaxis induced by HCC-1, MIP-1a and RANTES $\left(I C_{50}=23,25\right.$ and $13.1 \mathrm{ng} / \mathrm{ml}$, respectively), and intracellular calcium mobilization.

Conclusion: These results demonstrate that bioinformatics and protease digestion are feasible to screen and prepare C18P, and that C18P is a novel and specific small molecule peptide antagonist of CCR1 with therapeutic potential for preventing cell migration.
\end{abstract}

Keywords: CC Chemokine receptor 1; Simulated peptide-cut; Antagonist peptide; Viral macrophage inflammatory protein II; Bioinformatics; Protease digestion; HEK293 cells; Radioligand binding

Tropical Journal of Pharmaceutical Research is indexed by Science Citation Index (SciSearch), Scopus, International Pharmaceutical Abstract, Chemical Abstracts, Embase, Index Copernicus, EBSCO, African Index Medicus, JournalSeek, Journal Citation Reports/Science Edition, Directory of Open Access Journals (DOAJ), African Journal Online, Bioline International, Open-J-Gate and Pharmacy Abstracts

\section{INTRODUCTION}

Chemokines belong to a large family of small, basic proteins (approximately $8-17 \mathrm{kDa}$ ) that bind to and activate $\mathrm{G}$ protein-coupled receptors (GPCRs), and elicit a series of physiological responses including cell migration. CCR1 binds and responds to multiple endogenous proinflammatory chemokines such as MIP-1 $1 \alpha / C C L 3$, RANTES/CCL5, MCP-2/CCL8, MCP-4/CCL13 and HCC-1/CCL14 [1]. Among these chemokines, HCC-1 is specific for receptor CCR1 present in high concentrations in normal human plasma. VMIP-II, a broad-spectrum chemokine receptor antagonist encoded by $\mathrm{K} 4$ sequence in human herpes virus 8 genome, is capable of interacting with both $\mathrm{CC}$ and $\mathrm{CXC}$ chemokines receptors [2]. Several peptides derived from VMIP-II have been studied for their ability to block ligand/receptor interaction. 
Chemokine/chemokine receptor interactions have been validated to be targets owing to their involvement in physiopathological disorders and development of many diseases. In addition to induce cell migration, evidences have suggested that CCR1 is involved in bone remodeling by mechanical loading [3], and the regulation of stemness of adipose tissue derived stromal cells (ADSCs) [4]. It has been shown that, CCR1, in terms of disease progression, plays a significant role in the pathogenesis of multiple sclerosis [5], rheumatoid arthritis (RA) [6], graft-versus-host disease (GVHD) [7], and allergic encephalomyelitis [8]. For the treatment of these diseases, antagonism of CCR1 has become an appealing therapeutic target.

It is well known that several small molecule drug discovery efforts on chemokine receptors, such as CXCR4, CCR1 and CCR5, have been undertaken over the last several years [9]. Numerous articles have been published, at the same time, on the interactions between CCR1 and its ligands with small molecule antagonists. A number of CCR1 antagonists, including CP481715, BX471 and AZD-4818, have been described up to now $[9,10]$.

In this work, structure-based sequence alignment, simulated peptide-cut and bioinformatics analysis were used to search for peptide derived from VMIP-II with the function to block ligand/CCR1 interaction. To prepare peptide $\mathrm{C} 18 \mathrm{P}$, protease was used for the first time to digest VMIP-II. We evaluated the potential of C18P to dose-dependently inhibit the binding of MIP-1 $\alpha$ and RANTES to CCR1-expressing cells, blocking HCC-1 induced $\left[{ }^{35}\right.$ S]GTPYS binding, plus ligands induced intracellular calcium mobilization and chemotaxis. The aim of the present study was to screen a peptide containing 18 amino acids (C18P) derived from VMIP-II, and to further evaluate its potential as an efficient antagonist of CCR1.

\section{EXPERIMENTAL}

\section{Materials and reagents}

VMIP-II, C18P and ${ }^{3} \mathrm{H}-\mathrm{C} 18 \mathrm{P}$ were prepared by the Institute of Genomic Medicine Jinan University (Guangzhou, China). ${ }^{125}$ I-Labeled MIP-1 $\alpha$ and ${ }^{125}$ I-labeled RANTES were obtained from Amersham Pharmacia Biotech (Buckinghamshire, UK). All other chemokines used in the article were purchased from PeproTech (Rocky Hill, USA). Fetal serum albumin was obtained from Invitrogen. Bovine serum albumin was purchased from Roche Group. Cell culture reagents, L-glutamine and
Hepes were obtained from Gibco (Rockville, USA).

\section{Cells and cell culture}

Human CCR1-transfected HEK293 cells were generated as previously described [11], and maintained in Geneticin for selection, split twice per week, discarded after passage 12. The human monocytic cell line (THP-1) was maintained in RPMI 1640 medium and split $24 \mathrm{~h}$ before use. RPMI 1640 medium supplemented with fetal bovine serum (10\%), L-glutamine (2 $\mathrm{mM})$, Hepes $(10 \mathrm{mM})$, penicillin $(100 \mathrm{U} / \mathrm{ml})$, Lglutamine $(2 \mathrm{mM})$, and streptomycin $(50 \mu \mathrm{g} / \mathrm{ml})$.

\section{Screening and preparation of C18P}

After sequence alignment, 38 kinds of proteases offered by PeptideCutter were utilized to the simulated peptide-cut of VMIP-II. Peptide fragments including the conserved residues were picked out and analyzed using ProtParam. Vector NTI Advance software was used to build a computer model of final option based on the solved structure of VMIP-II. In line with the result of screening, suitable effective protease was chosen to digest VMIP-II under the most effective condition. Dialysis, gel filtration chromatography and repeated high performance liquid chromatography were performed together to purify the final selected peptide. The molecular weight of $\mathrm{C} 18 \mathrm{P}$ was tested using mass spectrometry.

\section{Chemokine and C18P binding studies}

Radioligand binding assays on human CCR1transfected HEK293 cells were conducted utilizing scintillation proximity assay (SPA) protocol. Cells were suspended in the assay buffer [50 mM Hepes (pH7.4), $5 \mathrm{mM} \mathrm{MgCl}, 1$ $\mathrm{mM} \mathrm{CaCl}, 0.5 \%$ bovine serum albumin] at a concentration of $2.5 \times 10^{5}$ cells $/ \mathrm{ml}$. 25,000 cells per well were then placed into a 96-well plate (Corning, USA) and mixed with $0.05-0.1 \mathrm{mg}$ WGA-SPA beads (Amersham Pharmacia Biotech, UK) in the presence or absence of various concentrations of $\mathrm{C} 18 \mathrm{P}$ at room temperature for $60 \mathrm{~min}$. The reaction in each well was started by adding $0.05 \mathrm{nM}^{125}$ |-labeled MIP$1 \alpha$ or ${ }^{125}$ /-labeled RANTES (specific activity, $2,200 \mathrm{Ci} / \mathrm{mmol}$ ) and radioactivity was counted using a scintillation counter (PerkinElmer Life Sciences, USA). Non-specific binding in competition studies was determined using 100 nM unlabeled MIP-1 $\alpha$ or RANTES. Similar procedures were performed in the presence of ${ }^{3} \mathrm{H}-\mathrm{C} 18 \mathrm{P}$. 


\section{$\left[{ }^{35} \mathrm{~S}\right] \mathrm{GTPYS}$ binding assay}

To assess the G-protein signaling, $\left[{ }^{35}\right.$ S]GTPYS binding assay was conducted by employing WGA-SPA assay technology. Cell membranes utilized for the assay were created as previously described [12] using THP-1 cells. Membranes $(100 \mu \mathrm{g})$ then were incubated in GTPYS binding buffer $(20 \mathrm{mM}$ Hepes, $5 \mathrm{mM} \mathrm{MgCl}, 100 \mathrm{mM}$ $\mathrm{NaCl}, \mathrm{pH} 7.4)$ containing $10 \mathrm{mM}$ GDP at room temperature for $20 \mathrm{~min}$. HCC-1 (100 nM) was added in the presence of different concentrations of C18P. ${ }^{35}$ S]GTPYS and WGA-SPA beads were also transferred to the membrane suspension 10 min later. The bound radioactivity of $\left[{ }^{35}\right.$ S]GTPYS binding was counted using a scintillation counter. Non-specific binding was measured in the presence of $100 \mu \mathrm{M}$ GTP. To evaluate the potential for inverse agonist activity, $\left[{ }^{35}\right.$ S $]$ GTPYS binding was also assessed on membranes in the presence of $\mathrm{C} 18 \mathrm{P}$ without adding $\mathrm{HCC}-1$.

\section{Isolation of human peripheral blood mononuclear cells (PBMCs)}

Heparinized sterile syringes were prepared for collecting human whole blood from healthy donors. Then immediately transferred diluted cell suspension to conical centrifuge tubes and centrifuged $30 \mathrm{~min}$ at $580 \times \mathrm{g}, 20{ }^{\circ} \mathrm{C}$. PBMCs were harvested from the interface and washed twice by adding excess hanks balanced salt solution (HBSS) and centrifuging $10 \mathrm{~min}$ at $280 \times$ $\mathrm{g}, 20^{\circ} \mathrm{C}$. Hypotonic lysis was used to remove any remaining red blood cells. Collected cells were then subjected to slow speed centrifugation $(150 \times \mathrm{g})$ to remove extra platelets. Cell toxicity of C18P was determined using MTT (3-(4,5dimethylthiazol-2-yl)-2,5-diphenyltetrazolium bromide) assay as previously described [13].

\section{Chemotaxis assay}

Measurement of PBMCs chemotaxis was conducted in 24-well ChemoTx microplates (Neuroprobe, USA) as follows. Briefly, $10 \mathrm{ng} / \mathrm{ml}$ different chemokines were loaded onto lower wells of the chamber filling with chemotaxis assay buffer [RPMI 1640 containing $0.5 \%$ bovine serum albumin (BSA) and $0.1 \%$ antibiotic] in a final volume of $600 \mu \mathrm{l}$. The $5 \mu \mathrm{m}$ pore polycarbonate filter (Neuroprobe, USA) was placed between the upper and lower wells of the chamber, and PBMCs $\left(2 \times 10^{6}\right.$ cells $\left./ \mathrm{ml}\right)$ in a volume of $100 \mu \mathrm{l}$ were loaded onto the filter in the presence or absence of different concentrations of C18P. Cell migration proceeded for $2 \mathrm{~h}$ in a humidified incubator at 37 ${ }^{\circ} \mathrm{C}$ with $5 \% \mathrm{CO}_{2}$, then the chamber was disassembled. The cells migrating into the lower chamber were collected and then transferred to 96-well plates (Corning, USA). The number of cells was quantified as previously described [14].

\section{Calcium mobilization experiments}

PBMCs were diluted to $2 \times 10^{6}$ cells $/ \mathrm{ml}$ with RPMI 1640 media in 24-well plates (Corning, USA).Then, chemokine or C18P was added to the cells for $24 \mathrm{~h}$ at $37{ }^{\circ} \mathrm{C}$ with $5 \% \mathrm{CO}_{2}$ in a humidified incubator. After washing twice and suspending at $1 \times 10^{7} \mathrm{cells} / \mathrm{ml}$ in serum-free RPMI 1640, PBMCs were loaded with $10 \mu \mathrm{M}$ (final concentration) Fluo-3/AM (Sigma, USA) for 30 min at $37{ }^{\circ} \mathrm{C}$ with $5 \% \mathrm{CO}_{2}$ in the dark. The cell suspension was then filtered after washing three times with HBSS containing $10 \mathrm{mM}$ Hepes. Calcium mobilization was tested using a flow cytometry FACSCalibur (BD Biosciences, USA) at excitation wavelengths of $488 \mathrm{~nm}$, and an emission wavelength of $530 \mathrm{~nm}$. To evaluate selectivity, PBMCs were loaded with Fluo-3/AM and stimulated with ligands specific for nonCCR1 receptors (Table 1), respectively.

\section{Data analysis}

Data are from replicate experiments and expressed as mean \pm SD. Student's $t$ test was used to evaluate the data. A value of $p<0.01$ or $p<0.05$ was considered to be statically significant.

Table1: Chemokines used in this study

\begin{tabular}{|c|c|c|c|c|c|}
\hline Receptor & Ligand & Common Name & Receptor & Ligand & Common Name \\
\hline \multirow[t]{5}{*}{ CCR1 } & CCL14 & $\mathrm{HCC}-1$ & CCR5 & CCL4 & MIP-1 $\beta$ \\
\hline & $\mathrm{CCL}^{*}$ & MIP-1a & CCR6 & CCL20 & MIP-3a \\
\hline & $\mathrm{CCL}^{*}$ & RANTES & CCR7 & CCL19 & MIP-3 $\beta$ \\
\hline & CCL8* & MCP-2 & CCR8 & CCL1 & I-309 \\
\hline & CCL13* & MCP-4 & CXCR1 & CXCL8 & IL-8 \\
\hline CCR2 & CCL2 & MCP-1 & CXCR3 & CXCL10 & IP-10 \\
\hline CCR3 & CCL24 & Eotaxin-2 & CXCR4 & CXCL12 & SDF-1 $1 \alpha$ \\
\hline
\end{tabular}

Note: Asterisk-labeled ligands are not specific for their receptors 


\section{RESULTS}

\section{Sequence alignment and structure analysis}

A sequence alignment of VMIP-II with several CCR1 binding chemokines is shown in Figure 1. As illustrated in the picture, conserved residues (binding sites), K45 and R46, are located in C- terminal near the core of the skeleton. The CCR1 binding model represents that a positively charged area is composed of K45 and R46, playing an essential role in binding to CCR1. Moreover, the spatial model displays that binding sites are located on the 40s ring and exposure to the surface of VMIP-II, contributing the binding sites to well combine with CCR1 (Figure 2A).

$$
\begin{aligned}
& \text { HCC-1 : - --TKTESSSRGPYHESECCETYTTYKI : } 25 \\
& \text { MIP-1A : -------SLAA--DTPTACCFSTTRQI : } 19 \\
& \text { RANTES : -------SPYS--SDTTPCCEAYIARPL : } 19 \\
& \text { MCP-2 : -------QPDS-VSIEITCCFNVINRKI : } 20 \\
& \text { MCP-4 : ENPQGLAQPDA-LNVESTCCETESSKKI : } 27 \\
& \text { VMIP-II : -----GDTLGASWHREDKCCLGYQKRPL : } 23 \\
& \text { MCP-1 : ------QPDA-INAEVTCCYNETNRKI：20 } \\
& \text { HCC-1 : PRQRTMDY-YETNSQCSKPGIVEITKRG : } 52 \\
& \text { MIP-1A : PQNEIADY-FETSSQCSKPGVIELTKRS : } 46 \\
& \text { RANTES : PRAHIKEY-FYTSGKCSNPANVEVTRKN : } 46 \\
& \text { MCP-2 : PIQRLESYTRITNIQCPKEAVIEKTKRG : } 48 \\
& \text { MCP-4 : SLQRLKSY-VITTSRCPQKAVIERTKLG : } 54 \\
& \text { VMIP-II : PQVLLSS团-YPTSQLCSKPGVIELTKRG : } 50 \\
& \text { MCP-1 : SVQRLASYRRITSSKCPKEAVIEKTIVA : } 48 \\
& \text { HCC-1 : HSVCTNESDKWVQDVYKDTKEN------ : } 74 \\
& \text { MIP-1A : ROVCADESEEWVQKYVSDLELSA----- : } 69 \\
& \text { RANTES : RQVCANEEKKTUVREYINSLEMS------ : } 68 \\
& \text { MCP-2 : KEVCADEKERWVRDSMKHLDQIEQNLKP : } 76 \\
& \text { MCP-4 : KEICADEKEKWVQNYMKHLGRKAHTLKT : } 82 \\
& \text { VMIP-II : RQVCADKSKDWVKKLMQQLPVTAR---- : } 74 \\
& \text { MCP-1 : KEICADEKQKGUVDSMDHLDKQTQT PKT : } 76
\end{aligned}
$$

Figure 1: An alignment of the amino acids sequences of VMIP-II and various CCR1 binding chemokines. The residues postulated to play a pivotal role in binding to CCR1 are highlighted by black dots. The box means the alignment exclusion criteria.

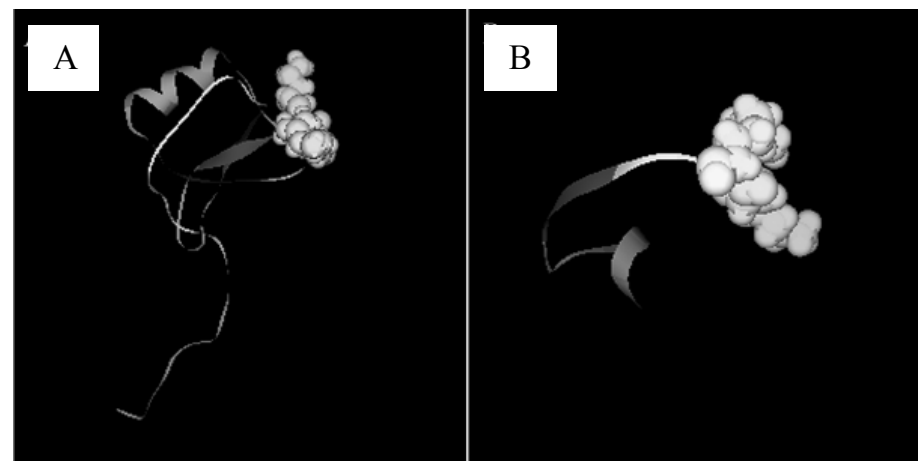

Figure 2: The structure of VMIP-II. Binding sites represented by balls are located on the 40 s ring and exposure to the surface of molecular (A). The predicted structure of C18P (B). The residues shown in balls indicate the binding sites. 


\section{Establishment of enzymatic peptide library and bioinformatics analysis}

VMIP-II was simulated peptide-cut into peptide fragments to establish the enzymatic peptide library. Stable peptide fragments containing binding sites and proteases were picked out after analyzing their physical and chemical properties using ProtParam tool (Table 2). This table shows that, C18P (TKRGRQVCADKSKDWVKK) with the minimum value of instability index is the most stable one of these peptide fragments. The physical and chemical properties of $\mathrm{C} 18 \mathrm{P}$ as follows: molecular weight, 2133.5; theoretical pl, 10.19; good stability under standard $\mathrm{pH}$ and stable expression in vitro. According to the results of bioinformatic analysis, C18P was screened to be the object of present study. Pepsin $(\mathrm{pH}>2)$ was chosen to digest VMIP-II in the following procedures. The structure of $\mathrm{C} 18 \mathrm{P}$ was predicted using Vector NTI Advance software as shown in Figure 2B. The picture shown also presents that $\mathrm{K} 45$ and $\mathrm{R} 46$ are located on the surface of the molecule.

Table 2: Stable peptide fragments and proteases

\begin{tabular}{lcc}
\hline Protease & Amount & $\begin{array}{l}\text { Instability } \\
\text { Index }\end{array}$ \\
\hline BNPS-Skatole & 30 & 23.97 \\
$\begin{array}{l}\text { Chymotrypsin- } \\
\text { high specificity }\end{array}$ & 16 & 21.16 \\
Chymotrypsin- & 15 & 21.90 \\
low specificity & 10 & 36.34 \\
Formic acid & 15 & 21.90 \\
lodosobenzoic acid & 9 & 39.27 \\
LysC & 14 & 22.75 \\
Pepsin (pH1.3) & 18 & $13.60^{*}$ \\
Pepsin (pH>2) & 33 & 22.04 \\
Proline-endopeptidase &
\end{tabular}

${ }^{*}$ Denotes the most stable peptide, C18P; amount presents the number of amino acids in each peptide fragment; instability index is measure of the instability of the peptide

\section{Detection of C18P}

The purity of peptide $\mathrm{C} 18 \mathrm{P}$ was tested more than $95 \%$ using high performance liquid chromatography. Mass spectrometry was utilized to verify the sequence of $\mathrm{C} 18 \mathrm{P}$. The molecular weight of C18P was calculated as 2133.96, which is consistent with the theoretical value.

\section{Identification of C18P}

Radioligand binding assays using human CCR1transfected HEK293 cells were applied to identify the potency of C18P to inhibit ${ }^{125}$ I-labeled MIP-1a and ${ }^{125}$-labeled RANTES binding to CCR1. As shown in Figure $3 \mathrm{~A}$, the competition binding experiments indicated that, in both the binding assays, C18P took the place of ${ }^{125}$ I-labeled MIP$1 \alpha$ and ${ }^{125}$-labeled RANTES from human CCR1transfected HEK293 cells in a dose-dependent manner, with median inhibitory concentration $\left(\mathrm{IC}_{50}\right)$ values of 11.2 and $9.6 \mathrm{ng} / \mathrm{ml}$, respectively. To better determine ligand/receptor interaction, similar binding assays were carried out in the presence of ${ }^{3} \mathrm{H}-\mathrm{C} 18 \mathrm{P}$. The data suggested that ${ }^{3} \mathrm{H}-\mathrm{C} 18 \mathrm{P}$ bound to human CCR1-transfected HEK293 cells with a $K d$ of $5.7 \mathrm{ng} / \mathrm{ml}$ (data not shown). Taken together, these results demonstrated that C18P blocked ligand/receptor interaction with the function of binding to human CCR1.

\section{Measurement of $\left[{ }^{35}\right.$ S $]$ GTPYS binding}

Because both agonist and/or antagonist can combine with CCR1, to further characterize its interaction, a WGA-SPA $\left[{ }^{35}\right.$ S]GTPYS binding assay was performed in cell membranes preparation from the perspective of function. As shown in Figure 3B, the adding of $\mathrm{C} 18 \mathrm{P}$ did not have remarkable influence on the basal level of receptor activity in the assay, demonstrating that $\mathrm{C} 18 \mathrm{P}$ did not act as an inverse agonist to stimulate G-protein signal transduction. On the contrary, interesting, $100 \mathrm{nM} \mathrm{HCC}-1$ induced $\left[{ }^{35}\right.$ S]GTPYS binding was significantly blocked by C18P in a concentration-dependent manner, with $\mathrm{IC}_{50}$ value of $3.7 \mathrm{ng} / \mathrm{ml}$.

\section{C18P inhibits PBMCs chemotaxis}

C18P was validated to lack cytotoxicity towards PMBCs, with survival rate of each treatment group $>80 \%$. To determine whether the C18P possesses immunogenicity, potential of C18P to induce PBMCs migration was examined in the chemotaxis assay. The chemotaxis indexes of all groups were $<2$ (data not shown) indicating that the $\mathrm{C} 18 \mathrm{P}$ lacked chemotactic capability (immunogenicity) from a perspective of statistic. The results correspond with those of $\left[{ }^{35} \mathrm{~S}\right] \mathrm{GTPYS}$ binding experiment. Ability of $\mathrm{C} 18 \mathrm{P}$ for inhibition of chemotaxis mediated by CCR 1 was investigated further. As shown in Figure 3C, chemotaxis induced by HCC-1, MIP-1 $\alpha$ and RANTES were strongly inhibited by $\mathrm{C} 18 \mathrm{P}$ in a concentration-dependent manner, with $\mathrm{IC}_{50}$ values of 23,25 and $13.1 \mathrm{ng} / \mathrm{ml}$, respectively. C18P did not have the potential to block PBMCs migration induced by ligands specific for nonCCR1 receptors (data not shown, Table 1), which was consistent with the results of radioligand binding assays. 

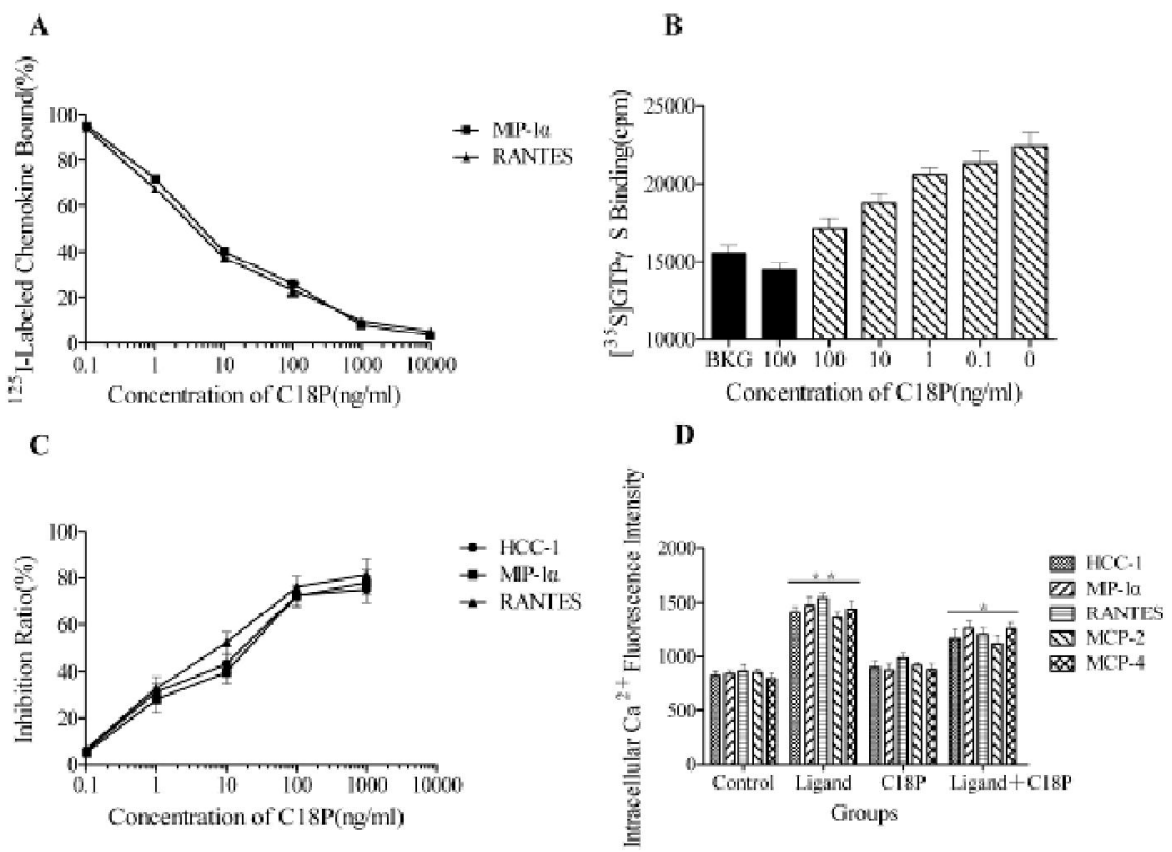

Figure 3: $A=C 18 P$ displaces radio-iodinated MIP-1 $\alpha$ and RANTES and binds to CCR1. This figure represents specific binding. Non-specific binding are 4.89 and $6.11 \%$ of the total added radio-iodinated MIP-1 $\alpha$ and RANTES, respectively; $\mathrm{B}=$ Inhibition of $\mathrm{HCC}-1$ induced $\left[{ }^{35} \mathrm{~S}\right] \mathrm{GTPYS}$ binding. THP-1 cell membranes were employed to assess $\left[{ }^{35}\right.$ S]GTPYS binding in the presence (slash bars) or absence(solid bars) of $100 \mathrm{nM} \mathrm{HCC}-1$; C $=$ Inhibition of ligand-stimulated PBMCs chemotaxis. $10 \mathrm{ng} / \mathrm{ml}$ chemokines were used to determine the PBMCs chemotaxis with increasing concentration of C18P; $\mathrm{D}=$ Inhibition of ligand-induced calcium mobilization. Nothing was added to control group. $10 \mathrm{ng} / \mathrm{ml}$ ligands and $100 \mathrm{ng} / \mathrm{ml} \mathrm{C18P}$ were used in group ligand and group C18P, respectively. The last group was handled with $100 \mathrm{ng} / \mathrm{ml} \mathrm{C18P}$ for $30 \mathrm{~min}$ before the experiments; * $p<0.05$, compared with ligand group; ${ }^{* *} p<0.01$, compared with control group.

\section{Effect of C18P on intracellular calcium mobilization}

To assess the effect of C18P on CCR1, changes of intracellular $\mathrm{Ca}^{2+}$ concentration in PBMCs were measured. We characterized whether $\mathrm{C} 18 \mathrm{P}$ have the potential to induce intracellular calcium mobilization. In the study, different concentrations of C18P had no direct effect on intracellular $\mathrm{Ca}^{2+}$ concentration (data not shown). In addition, C18P failed to inhibit calcium mobilization stimulated by ligands specific for non-CCR1 receptors (data not shown, Table 1).These results were consistent with those of above-mentioned studies. In contrast, as shown in Figure 3D, calcium mobilization induced by CCR1 ligands, such as HCC-1, MIP-1a, RANTES, MCP-2, MCP-4, were dramatically blocked by C18P $(100 \mathrm{ng} / \mathrm{ml})$. C18P had no noticeable influence on intracellular calcium mobilization, being identical to the results of initial step of these experiments.

\section{DISCUSSION}

Since the initial identification of CCR1 as a

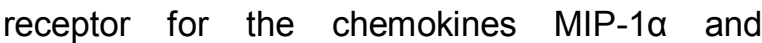
RANTES [15], the biology around CCR1 has been widely investigated over the last decades. A large number of studies have been published to support CCR1 as an attractive therapeutic target associating with leukocyte infiltration modulation and autoimmune diseases development.

Up to now, there have been a variety of small molecule antagonists of CCR1 entering phases of clinical studies, such as MLN3897 and CP$481715[16,17]$. These antagonists bind to chemokine receptors, but do not initiate cytoplasmic signal transduction cascades. Normal physiological functions of chemokine receptors can be inhibited by these antagonists. Screening of antagonists for their ability to bind to chemokine receptors is an important consideration when developing anti-inflammatory therapies. Therefore, a novel and functional antagonist peptide, C18P, that can bind to CCR1 and inhibit ligand/receptor interaction, G-protein signaling, cell migration, and calcium mobilization, is described here.

In this contribution, the conserved residues, K45 and R46, were postulated to play an essential role in CCR1 binding owing to their favorable spatial location. C18P containing two conserved 
residues was screened from the peptide library, which was set up by collecting all peptide fragments derived from simulated peptide-cutting VMIP-II for the first time. In addition, C18P has potential to act as an orally drug from the perspective of administration due to its corresponding protease, pepsin. Given the importance of molecular conformation in terms of biological activity [18], C18P structural model generated from the crystal structure of VMIP-II was built up. Overall, the findings are consistent with the prediction, proving that bioinformatics method was feasible to predict receptor binding site. Digestion based on simulated peptide-cut and utilized in practice was validated to be workable.

In our studies, C18P was assessed to be a specific and competitive antagonist peptide of human CCR1. The abilities of various CCR1 ligands to stimulate multiple functions on human CCR1-transfected HEK293 cells and THP-1 cells expressing CCR 1 were restrained by $\mathrm{C} 18 \mathrm{P}$, showing that C18P directly combined with CCR1, and did not behave as an inverse agonist because of being estimated its lack of immediate impact on ${ }^{35}$ S]GTPYS binding. $\left[{ }^{35}\right.$ S]GTPYS binding, the initial step following receptor ligation [19], was blocked by $\mathrm{C} 18 \mathrm{P}$ with higher $\mathrm{IC}_{50}$ but at concentration analogous to that necessary for inhibition of radioligand binding and chemotaxis. $\mathrm{C} 18 \mathrm{P}$ did not be regarded as an intrinsic agonist because of failing to induce chemotaxis and calcium mobilization. Moreover, C18P also lacked potency to directly block cell migration and intracellular $\mathrm{Ca}^{2+}$ concentration elevation induced by various specific ligands for non-CCR 1 receptors.

Furthermore, studies of the effect of C18P on chemotaxis and calcium mobilization showed that treatment with $\mathrm{C} 18 \mathrm{P}$ can efficiently inhibit PBMCs migration and elevation of $\mathrm{Ca}^{2+}$ concentration induced by CCR1 ligands, which further indicate the CCR1 antagonist role of $\mathrm{C} 18 \mathrm{P}$. The result of calcium mobilization is supported by a previous study which demonstrated that chemokines can increase intracellular $\mathrm{Ca}^{2+}$ concentration [2]. As such, it is reasonable to conclude that $\mathrm{C} 18 \mathrm{P}$ is acting specifically against CCR1 and exerts its function to block cell activity induced by CCR1 ligands.

\section{CONCLUSION}

The findings of this study highlight a novel and specific small molecule antagonist peptide of CCR1 derived from VMIP-II, and uncover that C18P may be developed to be an oral antagonist peptide. This work further shows that simulated peptide-cut of VMIP-II based on bioinformatics can be achieved in reality. All the results demonstrate that peptide $\mathrm{C} 18 \mathrm{P}$ is an antagonist of CCR1, and a potential candidate for the treatment of multiple diseases, including inflammation and rheumatoid arthritis.

\section{ACKNOWLEDGEMENT}

This research was supported by Guangdong Province Major Projects of Key Areas \{YS no. (2005)162\}, and Major Technology Program Funded Projects, Guangzhou (2011Y1-00017-3). Sha Liu and Qing Ding equally contributed to this work.

\section{REFERENCES}

1. Lazennec G, Richmond A. Chemokines and chemokine receptors: new insights into cancer-related inflammation. Trends Mol Med 2010; 16: 133-144.

2. Kledal TN. A Broad-Spectrum Chemokine Antagonist Encoded by Kaposi's Sarcoma-Associated Herpesvirus. Science 1997; 277: 1656-1659.

3. Taddei SR, Queiroz-Junior CM, Moura AP, Andrade I, Jr., Garlet GP, Proudfoot AE, Teixeira MM, da Silva TA. The effect of CCL3 and CCR1 in bone remodeling induced by mechanical loading during orthodontic tooth movement in mice. Bone 2013; 52: 259-267.

4. Kauts $M L$, Pihelgas S, Orro K, Neuman T, Piirsoo A. CCL5/CCR1 axis regulates multipotency of human adipose tissue derived stromal cells. Stem Cell Res 2013; 10: 166-178.

5. Liang M, Mallari C, Rosser M, Ng HP, May K, Monahan S, Bauman JG, Islam I, Ghannam A, Buckman B et al. Identification and characterization of a potent, selective, and orally active antagonist of the CC chemokine receptor-1. J Biol Chem 2000; 275: 19000-19008.

6. Koch $A E$, Kunkel SL, Strieter RM. Cytokines in rheumatoid arthritis, J Investig Med 1995; 1: 28-38.

7. Choi SW, Hildebrandt GC, Olkiewicz KM, Hanauer DA, Chaudhary MN, Silva IA, Rogers CE, Deurloo DT, Fisher JM, Liu C et al. CCR1/CCL5 (RANTES) receptor-ligand interactions modulate allogeneic $T$ cell responses and graft-versus-host disease following stem-cell transplantation. Blood 2007; 110: 3447-3455.

8. Rottman JB, Slavin AJ, Silva R, Weiner HL, Gerardand CG, Hancock WW. Leukocyte recruitment during onset of experimental allergic encephalomyelitis is CCR1 dependent, Eur J Immunol 2000; 30: 23722377.

9. Therapeutic targeting of chemokine receptors by small molecules. Drug Discov Today Technol 2012; 9: e227-314.

10. Gladue RP, Brown MF, Zwillich SH. CCR1 Antagonists:What have we learned from clinical trials, Curr Top Med Chem 2010; 10: 1268-1277.

11. Allen SJ, Ribeiro S, Horuk R, Handel TM. Expression, purification and in vitro functional reconstitution of the chemokine receptor CCR1. Protein Expr Purif 2009; 66: 73-81.

12. Hall DA, Beresford Isabel JM, Browning C, Giles $H$. Signalling by CXC-chemokine receptors 1 and 2 expressed in $\mathrm{CHO}$ cells: a comparison of calcium mobilization, inhibition of adenylylcyclase and stimulation of GTPYS binding induced by IL-8 and GROa, Br J Pharmacol 1999; 126: 810-818 
13. Liu H, Sun H, Li L, Mo X, Li X, Zhang G. Screening and Mechanism of Trapping Ligand Antagonist Peptide for Chemokine Receptor US28 of Human Cytomegalovirus. Trop J Pharma Res 2012; 11.

14. Yeap SK, Alitheen NB, Ali AM, Omar AR, Raha AR, Suraini AA, Muhajir AH. Effect of Rhaphidophora korthalsii methanol extract on human peripheral blood mononuclear cell (PBMC) proliferation and cytolytic activity toward HepG2. J Ethnopharmacol 2007; 114: 406-411.

15. Neote K, DiGregorio D, Mak JY, Horuk R, Schall TJ. Molecular cloning, functional expression, and signaling characteristics of a CC chemokine receptor. Cell 1993; 72: 415-425.

16. Vergunst CE, Gerlag DM, von Moltke L, Karol M, Wyant T, Chi X, Matzkin E, Leach T, Tak PP. MLN3897 plus methotrexate in patients with rheumatoid arthritis: Safety, efficacy, pharmacokinetics, and pharmacodynamics of an oral CCR1 antagonist in a phase Ila, double-blind, placebo-controlled, randomized, proof-of-concept study. Arthritis \& Rheumatism 2009; 60: 3572-3581.

17. Clucas AT, Shah A, Zhang YD, Chow VF, Gladue RP. Phase I evaluation of the safety, pharmacokinetics and pharmacodynamics of CP-481,715. Clinical pharmacokinetics 2007; 46: 757-766.

18. Kalani MY, Vaidehi $N$, Hall SE, Trabanino RJ, Freddolino PL, Kalani MA, Floriano WB, Kam VW, Goddard WA, 3rd. The predicted $3 D$ structure of the human D2 dopamine receptor and the binding site and binding affinities for agonists and antagonists. Proc Natl Acad Sci U S A 2004; 101: 3815-3820.

19. Gladue RP, Tylaska LA, Brissette WH, Lira PD, Kath JC, Poss CS, Brown MF, Paradis TJ, Conklyn MJ, Ogborne KT et al. CP-481,715, a potent and selective CCR1 antagonist with potential therapeutic implications for inflammatory diseases. J Biol Chem 2003; 278: 40473-40480. 